\title{
Analisis Beban Kerja dan Perhitungan Waktu Baku dengan Metode Stopwatch Time Study pada Operator SPBU XYZ
}

\author{
Dinda Amelia Wahyuningrum ${ }^{1}$, Yuri Delano Regent Montororing ${ }^{2 *}$, Denny Siregar ${ }^{3}$ \\ 1,2,3Program Studi Teknik Industri, Universitas Bhayangkara Jakarta Raya, Indonesia \\ ("yuri.delano@dsn.ubharajaya.ac.id)
}

\begin{abstract}
Abstrak - Penelitian ini mengidentifikasi beban kerja mental operator SPBU XYZ dengan menggunakan kuesioner National Aeronautic and Space Administration-Task Load Index (NASA-TLX) dan perhitungan tingkat kelelahan kerja untuk menganalisis tingginya beban kerja mental pada operator SPBU. Perhitungan tingkat kelelahan kerja menggunakan metode Subjective Self Rating Test (SSRT) dari kuesioner Industrial Fatigue Research Committee (IFRC). Upaya yang dilakukan untuk menurunkan tingkat beban kerja mental operator, dilakukan dengan menghitung waktu standar dengan menggunakan metode Stopwatch Time Study. Hasil perhitungan beban kerja mental operator SPBU menunjukkan beban kerja mental yang didapatkan operator berlebih dengan total rata-rata sebesar 77,35. Dimana indikator beban kerja mental yang memiliki skor tertinggi yaitu effort, temporal demand, dan physical demand. Dan hasil perhitungan tingkat kelelahan kerja operator 37,75 dengan klasifikasi kelelahan sedang. Setelah dilakukan perhitungan waktu standar, terjadi penyesuaian waktu kerja. Dimana waktu siklus rata-rata kerja sebelumnya 8,24 menit menjadi 12,29 menit. Penyesuaian waktu kerja merupakan persentase penurunan 3 indikator tertinggi beban kerja mental operator. Setalah dilakukan perhitungan untuk menurunkan beban kerja mental, skor akhir yang didapatkan adalah 52,30 dengan klasifikasi beban kerja mental optimal load dan kenaikan persentase utilitas stasiun pengisian bahan bakar sebesar $32 \%$.
\end{abstract}

Kata kunci: beban kerja mental; ergonomi; kelelahan kerja; NASA-TLX; time study; waktu standar

\section{PENDAHULUAN}

SPBU (Stasiun Pengisian Bahan Bakar untuk Umum) adalah prasarana umum yang disediakan oleh PT Pertamina untuk memfasilitasi kebutuhan bahan bakar masyarakat luas. SPBU XYZ adalah salah satunya, terletak di Bekasi Utara yang memiliki 8 jalur pengisian dengan beberapa jenis bahan bakar yaitu, pertalite, pertamax, pertamina dex. Pengoperasian pengisian bahan bakar di SPBU XYZ masih menggunakan tenaga kerja manusia, dengan posisi berdiri secara terus menerus. Meski telah banyak pom mini yang beredar di daerah Bekasi Utara, tetapi SPBU XYZ masih banyak diminati oleh masyarakat, terbukti dari hasil pengamatan yang dilakukan penulis bahwa hanya dalam waktu kurang dari satu jam, operator SPBU telah melayani kurang lebih 100 kendaraan bermotor. Ramli (2010) dan Hämäläinen, dkk (2017) menjelaskan bahwa fenomena yang terjadi tersebut memungkinkan munculnya beban kerja pada operator SPBU, dan hal tersebut terbukti dari hasil pengamatan dan wawancara terkait utilitas stasiun pengisian bahan bakar yang dilakukan oleh penulis selama satu bulan proses penelitian.

Tabel 1

Data utilitas (\%) stasiun pengisian bahan bakar SPBU XYZ

\begin{tabular}{lcccc}
\hline Minggu & Stasiun 1 & Stasiun 2 & Stasiun 3 & Stasiun 4 \\
\hline Minggu ke 1 & 100 & 100 & 100 & 71 \\
Minggu ke 2 & 100 & 86 & 86 & 100 \\
Minggu ke 3 & 71 & 100 & 86 & 57 \\
Minggu ke 4 & 100 & 71 & 100 & 86 \\
\hline
\end{tabular}

Stasiun 1 dan 4 adalah dispenser pengisian kendaraan bermotor dengan jenis bahan bakar pertalite dan pertamax, stasiun 2 adalah pam pengisian bahan bakar mobil dengan bahan bakar pertalite dan pertamax, stasiun 3 adalah pam pengisian bahan bakar mobil dan mobil box atau truk dengan bahan bakar pertamax, pertamina dex dan pertalite. Pihak Manajemen SPBU telah menetapkan standar utilitas stasiun pengisian bahan bakar agar mencapai target yang telah ditetapkan, yaitu minimal 86\%. Dari data di atas, dapat dilihat bahwa dalam satu bulan hanya pada minggu ke-2 SPBU XYZ mampu mencapai target. sedangkan pada minggu ke1 utilitas yang tidak memenuhi standar yaitu stasiun 4 dengan persentase utilitas $71 \%$, minggu ke-3 pada stasiun 1 dan stasiun 4 dengan masing-masing persentase utilitas $71 \%$ dan $57 \%$, dan pada minggu ke-4 yang 
tidak memenuhi standar yaitu pada stasiun 2 dengan persentase utilitas $71 \%$. Setelah dilakukan wawancara, penyebab tidak terpenuhinya standar utilitas pada stasiun pengisian bahan bakar SPBU XYZ yaitu ketidakhadiran operator SPBU yang dikarenakan kondisi kesehatan operator. Dapat dilihat bahwa 2 stasiun pengisian yang melayani kendaraan bermotor dalam satu bulan tidak mampu untuk mencapai target dan dari hasil pengamatan, kendaraan bermotor memang memiliki frekuensi yang tinggi. Operator SPBU XYZ bekerja dalam waktu normal yaitu 8 jam per hari dengan pembagian 2 shift, dimana shift I dimulai dari pukul 07.00 15.00 dan shift II dimulai dari pukul 15.00 - 23.00, pembagian shift kerja pada operator bergilir setiap satu pekan. Dalam satu shift operator diberikan waktu istirahat bergilir hanya 30 menit, dengan posisi kerja yang statis dan cukup lama menurut Tarwaka (2015), mempunyai kadar intensitas pembebanan fisik yang rendah akan tetapi memiliki intensitas pembebanan mental yang tinggi.

Dalam upaya pengurangan beban kerja pada operator SPBU XYZ dapat dilakukan dengan menghitung waktu standar yang dibutuhkan operator untuk menyelesaikan satu siklus elemen kerja yang dilakukannya.

Berdasarkan uraian tersebut, maka penelitian ini bertujuan untuk :

1. Menganalisis beban kerja mental dan kelelahan kerja pada operator SPBU XYZ.

2. Menghitung waktu standar yang dibutuhkan operator SPBU XYZ untuk menyelesaikan satu siklus pekerjaannya.

3. Melakukan analisis untuk mencapai target utilitas pada stasiun pengisian bahan bakar.

\section{STUDI LITERATUR}

\section{A. Ergonomi}

Kata ergonomi berasal dari bahasa Yunani yang mengandung dua suku kata, yaitu "Ergon" dan "Nomos". Kata Ergon yang memiliki arti kerja dan Nomos adalah aturan atau hukum. Secara ringkas istilah ergonomi dapat diartikan sebagai suatu aturan atau norma dalam sebuah sistem kerja (Iridiastadi \& Yassierli, 2014) (Sutalaksana, 2006).

\section{B. Beban Kerja}

Menurut Meshkati dalam jurnal Widyanti, dkk (2010), definisi dari beban kerja adalah adanya perbedaan antara kemampuan pekerja dengan tanggung jawab pekerjaan.

Menurut Tarwaka (2015) beban kerja mental berdasarkan aspek fisiologi, aktivitas mental terlihat sebagai suatu pekerjaan yang dianggap tidak terlalu berat atau bersifat ringan, karena kebutuhan kalori untuk aktivitas mental juga lebih rendah dibandingkan dengan aktivitas fisik.

Pengukuran beban kerja psikologi secara subjektif dapat dilakukan dengan National Aeronautics and Space Administration-Task Load Index (NASA-TLX). NASA-TLX adalah alat yang dapat digunakan untuk mengukur beban kerja mental pekerja dengan 6 indikator beban kerja yaitu mental demand (Kebutuhan Mental), physical demand (Kebutuhan Fisik), temporal demand (Kebutuhan Waktu), own performance (Performansi), frustration level (Tingkat Stres), dan effort (Usaha).

Pengolahan data beban kerja mental dilakukan melalui proses perhitungan dengan langkah-langkah perhitungan yang dilakukan sebagai berikut (Hart \& Staveland, 1998):

1. Menghitung nilai WWL (Weighted Workload) yaitu dengan mengalikan nilai pembobotan dengan rating dari setiap indikator.

$$
\mathrm{WWL}=\text { Bobot } \mathrm{x} \text { Rating }
$$

2. Menghitung rata-rata WWL dengan cara membagi total nilai WWL dari satu responden dengan jumlah total bobot yaitu 15 .

$$
\text { Rata-rata } \mathrm{WWL}=\frac{W W L}{15}
$$




\section{Kelelahan Kerja}

Perasaan yang muncul dari dalam tubuh sebagai suatu mekanisme perlindungan tubuh agar terhindar dari kerusakan lebih lanjut disebut kelelahan (Pratiwi, dkk. 2019) (Wignjsoebroto, 2008). Terdapat beberapa cara untuk melakukan pengukuran tingkat kelelahan kerja dengan Subjective Feelings of Fatigue, Pengukuran kelelahan secara subjektif atau Subjective Self Rating Test dari Industrial Fatigue Research Committee (IFRC) Jepang, berbentuk kuesioner untuk mengukur tingkat kelelahan secara subjektif. Kuesioner IFRC berjumlah 30 pertanyaan yang terdiri dari, 10 pertanyaan pertama tentang pelemahan kegiatan, 10 pertanyaan kedua tentang pelemahan motivasi kerja dan 10 pertanyaan terakhir tentang gambaran kelelahan fisik yang dialami pekerja atau responden.

\section{Waktu Standar}

Waktu standar adalah hasil dari perhitungan waktu, metode perhitungannya dengan menggunakan metode stopwatch time study. Waktu standar adalah waktu yang dibutuhkan operator untuk menyelesaikan satu siklus elemen kerja yang dilakukannya dengan adanya pertimbangan faktor penyesuaian yang berlandaskan kemampuan pekerja dan ditambah kelonggaran waktu untuk keperluan pribadi (Montororing, 2018).

- Metode Stopwatch Time Study

Tahapan perhitungan waktu standar:

1. Pengukuran Waktu Siklus Kerja

Dalam pengambilan data waktu siklus kerja menggunakan metode snapback atau berulang-ulang. Pengukuran waktu dilakukan secara langsung dan menggunakan alat ukur jam henti atau stopwatch.

2. Pengujian Data (Uji Statistik Data)

\section{- Uji Normalitas Data}

Bertujuan untuk menguji apakah data waktu siklus pengamatan yang diperoleh dari pengamatan berdistribusi normal atau tidak. Uji Normal mengukur penyimpangan data waktu yang diambil. Uji Normalitas data dilakukan menggunakan software Minitab 16 dengan Kolmonogorof-Smirnov test (Montororing, 2021).

\section{- Uji Keseragaman Data}

Bertujuan untuk memastikan bahwa data yang diambil seragam, atau tidak ada yang melewati Batas kontrol Atas (BKA), dan Batas Kontrol Bawah (BKB).

$$
\begin{aligned}
& \mathrm{BKA}=\overline{\bar{X}}+3 \sigma \bar{x} \\
& \mathrm{BKB}=\overline{\bar{X}}-3 \sigma \bar{x}
\end{aligned}
$$

\section{- Uji Kecukupan Data}

Uji kecukupan data dilakukan untuk mengetahui apakah data yang telah didapatkan cukup untuk kemudian dilakukan perhitungan selanjutnya.

$$
\mathrm{N}^{\prime}=\left(\frac{k \sqrt{N \sum x_{i}^{2}-\left(\sum x_{i}\right)^{2}}}{s \sum x_{i}}\right)^{2}
$$

- Perhitungan Waktu Normal

$$
\mathrm{Wn}=\mathrm{Ws} \times \text { Perfomance rating }(p)
$$

\section{- Perhitungan Waktu Standar}

$$
\mathrm{Ws}=\frac{\mathrm{Wn} \times 100}{100-\text { allowance(\%) }}
$$




\section{E. Faktor Penyesuaian}

Dalam buku Yanto dan Ngaliman (2017), penyesuaian adalah faktor yang diberikan kepada pekerja sesuai dengan kemampuan performa yang dimiliki pekerja, tetapi harus sesuai dengan konsep kerja wajar.

Tabel 2

Nilai faktor penyesuaian metode Westinghouse

\begin{tabular}{|c|c|c|c|c|c|c|c|c|c|}
\hline \multicolumn{2}{|l|}{ SKILL } & & \multicolumn{3}{|c|}{ EFFORT } & \multicolumn{2}{|c|}{ CONDITION } & \multicolumn{2}{|c|}{ CONSISTENCY } \\
\hline$+0,15$ & A1 & Superskill & $+0,13$ & A1 & Superskill & $+0,06 \quad \mathrm{~A}$ & Ideal & $+0,04 \quad \mathrm{~A}$ & Ideal \\
\hline$+0,13$ & $\mathrm{~A} 2$ & & $+0,12$ & A2 & & $+0,04 \mathrm{~B}$ & Excellent & $+0,03 \quad \mathrm{~B}$ & Excellent \\
\hline$+0,11$ & B1 & Excellent & $+0,10$ & B1 & Excellent & $+0,02 \mathrm{C}$ & Good & $+0,01 \mathrm{C}$ & Good \\
\hline$+0,08$ & B2 & & $+0,08$ & B2 & & $0,00 \quad \mathrm{D}$ & Average & $0,00 \quad \mathrm{D}$ & Average \\
\hline$+0,06$ & $\mathrm{C} 1$ & Good & $+0,05$ & $\mathrm{C} 1$ & Good & $-0,03 \quad E$ & Fair & $-0,02 \quad E$ & Fair \\
\hline$+0,03$ & $\mathrm{C} 2$ & & $+0,02$ & $\mathrm{C} 2$ & & $-0,07 \quad F$ & Poor & $-0,04 \quad F$ & Poor \\
\hline 0,00 & $\mathrm{D}$ & Average & 0,00 & $\mathrm{D}$ & Average & & & & \\
\hline$-0,05$ & E1 & Fair & $-0,04$ & E1 & Fair & & & & \\
\hline$-0,10$ & E2 & & $-0,08$ & E2 & & & & & \\
\hline$-0,16$ & $\mathrm{~F} 1$ & Poor & $-0,12$ & F1 & Poor & & & & \\
\hline$-0,22$ & $\mathrm{~F} 2$ & & $-0,17$ & F2 & & & & & \\
\hline
\end{tabular}

\section{F. Faktor Kelonggaran}

1. Kelonggaran Untuk Kebutuhan Pribadi (Personal Allowance)

Kelonggaran ini diperlukan untuk mengakomodasi aktivitas-aktivitas yang bersifat alamiah tetapi mutlak dibutuhkan oleh pekerja. Aktivitas-aktivitas yang termasuk dalam kebutuhan personal allowance antara lain peregangan tubuh, mengobrol kecil-kecil untuk menghilangkan kejenuhan, minum, dan lain-lain.

2. Kelonggaran Untuk Menghilangkan Kelelahan (Fatique Allowance)

Kelonggaran ini diperlukan untuk pertimbangan dari aktivitas yang dikerjakan oleh pekerja untuk menghilangkan rasa lelah. Contoh faktor dari kelonggaran ini adalah memberikan nilai pada tenaga yang diperlukan apabila posisi kerja berdiri, sikap kerja, gerakan kerja, kelelahan mata, keadaan temperatur tempat kerja, keadaan atmosfer, dan keadaan lingkungan yang baik.

3. Kelonggaran Untuk Hal-hal yang Tidak Dapat Dihindari (Delay Allowance)

Delay allowance adalah kelonggaran yang diberikan kepada pekerja untuk hambatan-hambatan yang tidak dapat dihindari dan terjadi di luar kendali pekerja.

\section{METODOLOGI}

Pengumpulan data dilakukan dengan penyebaran kuesioner NASA-TLX untuk mengetahui beban kerja mental dan Kuesioner IFRC untuk mengetahui tingkat kelelahan kerja, kemudian wawancara untuk mengetahui informasi terkait SPBU dan pengamatan langsung untuk mendapatkan waktu siklus kerja operator yang pengukuran waktunya dilakukan dengan menggunakan stopwatch dan untuk melihat langsung kesesuaian hasil kuesioner dengan kondisi operator di lapangan ketika melakukan aktivitas kerja. Pada proses pengumpulan data beban kerja mental dan tingkat kelelahan kerja hanya berfokus pada operator dan tidak memperhatikan stasiun, karena setiap satu pekan operator akan bergantian shift, setiap operator memiliki pengalaman pada semua stasiun pengisian bahan bakar.

Studi pendahuluan dilaksanakan dengan melakukan observasi langsung dan pengumpulan data dari sumber literatur, sehingga didapatkan permasalahan yang dapat diangkat untuk dilakukan penelitian, yaitu terkait beban kerja yang didapatkan operator salah satu SPBU yang terletak di Bekasi Utara dan tentang waktu standar yang dibutuhkan operator SPBU untuk menyelesaikan satu siklus pekerjaannya. 


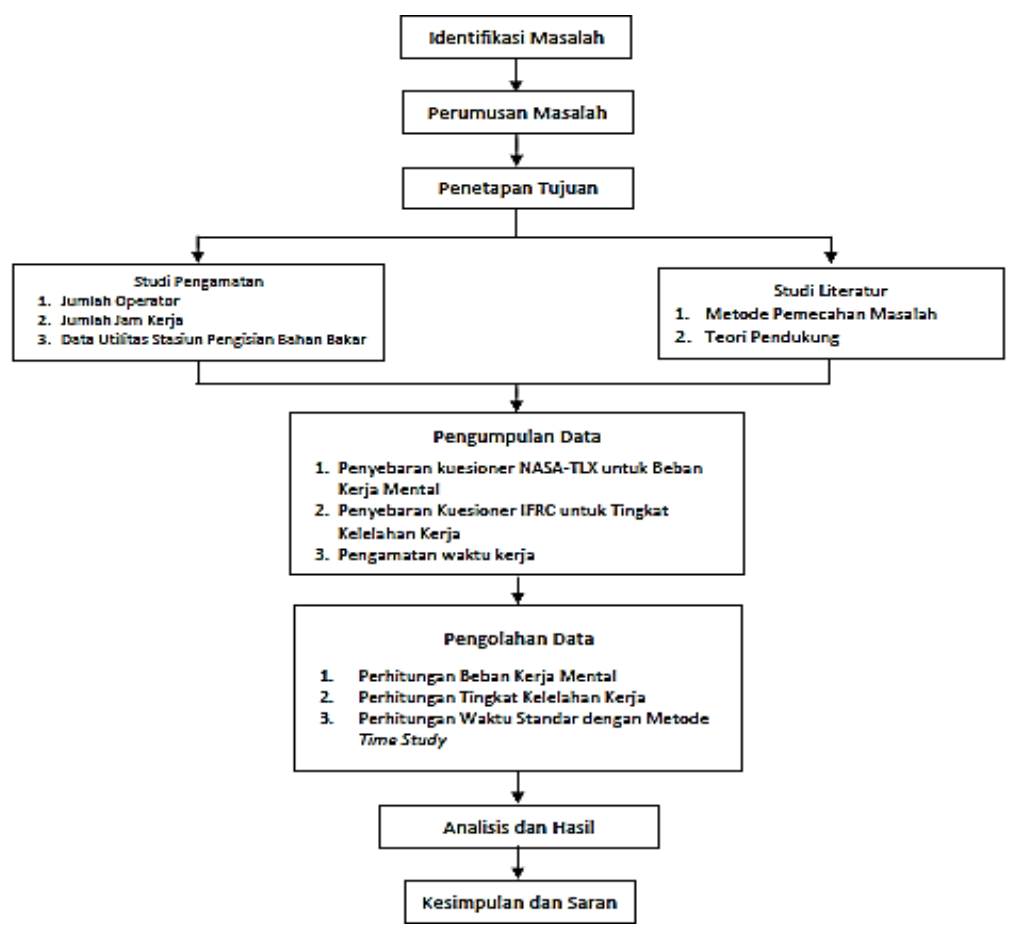

Gambar 1. Diagram alir penelitian

\section{HASIL DAN DISKUSI}

\section{A. Beban Kerja Mental}

Metode yang digunakan pada pengukuran tingkat beban kerja mental operator adalah NASA-TLX, dimana mengimplementasikannya terdapat dua tahapan pengumpulan data, yaitu pemberian pembobotan (Weigths) dan pemberian skor (Rating).

Tabel 3

Skor perhitungan beban kerja mental

\begin{tabular}{ccccccccccccc}
\hline \multirow{2}{*}{ Indikator } & \multicolumn{11}{c}{ Responden } \\
\cline { 2 - 13 } & Op 1 & Op 2 & Op 3 & Op 4 & Op 5 & Op 6 & Op 7 & Op 8 & Op 9 & Op 10 & Op 11 & Op 12 \\
\hline MD & 8 & 10,7 & 4 & 4,67 & 10,67 & 8 & 8,67 & 9,3 & 15 & 20 & 14 & 16 \\
PD & 16 & 18 & 18,67 & 16 & 15 & 14 & 12,67 & 24 & 12,67 & 26,67 & 21,3 & 9,3 \\
TD & 16 & 18 & 16 & 16 & 8 & 9 & 15 & 16 & 16 & 5,3 & 30 & 21,3 \\
P & 18 & 6 & 8 & 12 & 14 & 9 & 14 & 9,3 & 12,67 & 12 & 0 & 12 \\
FR & 2,67 & 4 & 5,3 & 6,67 & 5,3 & 9 & 6,67 & 3,3 & 9,3 & 16 & 5,3 & 0 \\
RF & 14 & 21,3 & 18,67 & 21,3 & 11,3 & 20 & 21,3 & 16 & 16 & 13,3 & 10,67 & 24 \\
Total & 74,7 & 78 & 70,67 & 76,7 & 64,3 & 69,3 & 78,3 & 78 & 81,67 & 93,3 & 81,67 & 82,67 \\
\hline
\end{tabular}

Tabel 4

Lanjutan skor perhitungan beban kerja mental

\begin{tabular}{ccccc}
\hline \multirow{2}{*}{ Indikator } & \multicolumn{4}{c}{ Responden } \\
\cline { 2 - 5 } & Op 13 & Op 14 & Op 15 & Op 16 \\
\hline MD & 10 & 9,3 & 12 & 17 \\
PD & 12 & 18 & 5,3 & 12 \\
TD & 5,3 & 18 & 20 & 25,3 \\
P & 9,3 & 14 & 16 & 12 \\
FR & 2,67 & 3,3 & 0 & 5 \\
EF & 23,3 & 16 & 26,67 & 17 \\
\hline Total & 62,67 & 78,67 & 80 & 88,3 \\
\hline
\end{tabular}


Tabel 5

Rekapitulasi rata-rata WWL seluruh operator 1-operator 16

\begin{tabular}{lcc}
\hline Indikator & Total WWL & Rata-rata \\
\hline Mental Demand (MD) & 177,28 & 11,08 \\
Physical Demand (PD) & 251,58 & 15,72 \\
Temporal Demand (TD) & 255,2 & 15,95 \\
Performance (P) & 178,27 & 11,14 \\
Frustation Level (FR) & 84,48 & 5,28 \\
Effort (EF) & 290,81 & 18,17 \\
\hline \multicolumn{2}{c}{ Total Beban Kerja Mental } & 77,35 \\
\hline
\end{tabular}

Tabel 6

Kategori beban kerja mental operator SPBU

\begin{tabular}{cccc}
\hline No. & Operator & Rata-rata WWL & Klasifikasi Beban Kerja Mental \\
\hline 1 & Operator 1 & 74,66 & Tinggi \\
2 & Operator 2 & 78 & Tinggi \\
3 & Operator 3 & 70,66 & Tinggi \\
4 & Operator 4 & 76,66 & Tinggi \\
5 & Operator 5 & 64,33 & Tinggi \\
6 & Operator 6 & 69,33 & Tinggi \\
7 & Operator 7 & 78,33 & Tinggi \\
8 & Operator 8 & 78 & Tinggi \\
9 & Operator 9 & 81,66 & Sangat Tinggi \\
10 & Operator 10 & 93,33 & Sangat Tinggi \\
11 & Operator 11 & 81,33 & Sangat Tinggi \\
12 & Operator 12 & 82,66 & Sangat Tinggi \\
13 & Operator 13 & 62,66 & Tinggi \\
14 & Operator 14 & 78,66 & Tinggi \\
15 & Operator 15 & 80 & Tinggi \\
16 & Operator 16 & 88,33 & Sangat Tinggi \\
\hline
\end{tabular}

Berdasarkan hasil perhitungan beban kerja mental operator SPBU XYZ dengan menggunakan metode NASA-TLX, didapatkan bahwa indikator beban kerja mental yang menghasilkan skor tertinggi adalah effort, kemudian temporal demand, physical demand, performance, mental demand, dan yang terakhir frustation level.

Berdasarkan data utilitas stasiun pengisian bahan bakar, dimana terdapat stasiun yang tidak mampu mencapai target, yaitu stasiun 1 dan 4 yang merupakan stasiun pengisian bahan bakar kendaraan bermotor dan stasiun 3 yang merupakan stasiun pengisian bahan bakar kendaraan mobil dan mobil box atau truk. Dari hasil pengamatan kendaraan yang selalu memiliki volume yang tinggi adalah kendaraan bermotor hal tersebut sesuai dengan hasil perhitungan beban kerja dimana indikator temporal demand atau tekanan waktu memiliki ratarata skor yang tinggi, dan untuk pengisian kendaraan roda 4 pada stasiun 3, operator harus mengerahkan tenaga tambahan karena operator harus mengangkat selang pengisian untuk mencapai tangki pengisian bahan bakar dan berdasarkan hasil pengamatan waktu siklus, pengisian bahan bakar roda 4 memakan waktu lebih lama dari pengisian bahan bakar motor. Faktor-faktor tersebut, sangat sesuai dengan hasil perhitungan beban kerja, karena ketika operator mengalami tekanan waktu, maka secara tidak langsung operator akan mengerahkan tenaga yang lebih untuk dapat melakukan pekerjaan dengan cepat sehingga meningkatkan tekanan fisik. Dan dua indikator tersebut dapat menyebabkan effort yang tinggi.

\section{B. Kelelahan Kerja}

Metode yang digunakan pada perhitungan kelelahan kerja operator SPBU XYZ adalah Subject Self Rating Test (SSRT) dengan kuesioner dari Industrial Fatique Research Committe, Jepang. Dimana terdapat 30 pertanyaan yang diajukan yaitu 10 pertanyaan pertama tentang pelemahan kegiatan, 10 pertanyaan kedua tentang pelemahan motivasi kerja dan 10 pertanyaan terakhir tentang gambaran kelelahan fisik yang dialami pekerja atau responden. Skor yang dihasilkan pada pengumpulan data yaitu berupa skala likert.

Setelah dilakukan perhitungan didapatkan hasil klasifikasi beban kerja yang dituangkan dalam tabel di bawah ini: 
Tabel 7

Hasil perhitungan kelelahan kerja operator SPBU XYZ

\begin{tabular}{clcc}
\hline No. & Operator & Total Skor & Klasifikasi Kelelahan \\
\hline 1 & Operator 1 & 21 & Rendah \\
2 & Operator 2 & 32 & Sedang \\
3 & Operator 3 & 39 & Sedang \\
4 & Operator 4 & 35 & Sedang \\
5 & Operator 5 & 23 & Sedang \\
6 & Operator 6 & 46 & Tinggi \\
7 & Operator 7 & 20 & Rendah \\
8 & Operator 8 & 28 & Sedang \\
9 & Operator 9 & 47 & Tinggi \\
10 & Operator 10 & 50 & Tinggi \\
11 & Operator 11 & 46 & Tinggi \\
12 & Operator 12 & 33 & Sedang \\
13 & Operator 13 & 48 & Tinggi \\
14 & Operator 14 & 50 & Tinggi \\
15 & Operator 15 & 34 & Sedang \\
16 & Operator 16 & 52 & Tinggi \\
\hline & Jumlah Total Skor & 604 & Sedang \\
\hline
\end{tabular}

Dalam pengukuran tingkat kelelahan kerja yang menggunakan kuesioner IFRC terdapat 30 pertanyaan gejala kelelahan sebagai indikator kelelahan kerja. Dari 16 responden jumlah rata-rata skor penilaian untuk kelelahan kerja yaitu 37,75, yang berarti tingkat kelelahan kerja yang dialami oleh operator SPBU masuk ke dalam kategori kelelahan sedang yang dimana pihak perusahaan mungkin diperlukan adanya tindakan perbaikan dalam menyikapi dan mengatasi penyebab kelelahan kerja yang nantinya akan menimbulkan gangguan kesehatan pada operator tersebut. Dari 30 pertanyaan kelelahan kerja, terdapat 5 pertanyaan yang memiliki skor cukup tinggi, yaitu dimana operator sering menguap saat bekerja, mengantuk saat bekerja, merasa ingin berbaring saat bekerja, mengalami kaku di bagian bahu setelah bekerja, dan merasa sangat haus setelah bekerja. Meskipun kategori kelelahan operator SPBU XYZ sedang, tetapi dilihat dari 5 pertanyaan yang memiliki skor tertinggi tersebut, akan meningkatkan kelelahan kerja pada operator jika perusahaan mengabaikannya atau tidak mengambil tindakan untuk mengurangi rasa lelah pada operator.

\section{Waktu Standar}

Proses pengolahan data waktu standar dimulai dengan melakukan pengujian statistika pada data waktu siklus yang telah didapatkan dari hasil pengamatan. Dari tabel 8 dapat dilihat bahwa nilai-P ( $P$-Value) yang dihasilkan lebih besar dari 0,05, dengan demikian data waktu pelayanan berdistribusi normal.

Tabel 8

Rekapitulasi hasil uji normalitas data waktu pengamatan

\begin{tabular}{clc}
\hline No. & \multicolumn{1}{c}{ Elemen Pekerjaan } & Nilai-P \\
\hline 1. & Pelayanan Pengisian Bahan Bakar Montor dengan Pembayaran Cash & 0,150 \\
2. & Pelayanan Pengisian Bahan Bakar Mobil dengan Pembayaran Cash & 0,097 \\
3. & Pelayanan Pengisian Bahan Bakar Mobil dengan Pembayaran Debit & 0,150 \\
4. & Pelayanan Pengisian Bahan Bakar Truk dengan Pembayaran Cash & 0,150 \\
5. & Pelayanan Pengisian Bahan Bakar Truk dengan Pembayaran Debit & 0,061 \\
\hline
\end{tabular}

Berdasarkan hasil perhitungan BKA dan BKB dari data waktu setiap elemen pekerjaan, maka didapatkan hasil tidak adanya data yang melebihi batas kontrol atas (BKA) dan batas kontrol bawah (BKB), maka data dikatakan seragam dan tidak perlu ada yang dibuang. 
Tabel 9

Rekapitulasi hasil perhitungan keseragaman data

\begin{tabular}{clcccc}
\hline No. & Elemen Pekerjaan & BKA & BKB & Standar Deviasi & Rata-rata \\
\hline 1. & $\begin{array}{l}\text { Pelayanan Pengisian Bahan Bakar Motor } \\
\text { dengan Pembayaran Cash }\end{array}$ & 0,687 & 0,146 & 0,090 & 0,417 \\
2. & $\begin{array}{l}\text { Pelayanan Pengisian Bahan Bakar Mobil } \\
\text { dengan Pembayaran Cash }\end{array}$ & 1,277 & 0,4408 & 0,1394 & 0,858 \\
3. $\quad \begin{array}{l}\text { Pelayanan Pengisian Bahan Bakar Mobil } \\
\text { dengan Pembayaran Debit }\end{array}$ & 1,1477 & 0,2963 & 0,1419 & 0,722 \\
4. $\quad \begin{array}{l}\text { Pelayanan Pengisian Bahan Bakar Truk } \\
\text { dengan Pembayaran Cash }\end{array}$ & 4,7216 & 1,606 & 0,5192 & 3,164 \\
5elayanan Pengisian Bahan Bakar Truk & 4,484 & 1,682 & 0,467 & 3,083 \\
\hline
\end{tabular}

Berdasarkan hasil perhitungan uji kecukupan data waktu dari setiap elemen pekerjaan, maka didapatkan hasil sebagai berikut:

Tabel 10

Rekapitulasi hasil uji kecukupan data

\begin{tabular}{ccccc}
\hline No. & Elemen Pekerjaan & $N^{\prime}$ & N & Keterangan \\
\hline 1. & Pelayanan Pengisian Bahan Bakar Motor dengan Pembayaran Cash & 18,15 & 35 & Data Cukup \\
2. & Pelayanan Pengisian Bahan Bakar Motor dengan Pembayaran Cash & 10,23 & 35 & Data Cukup \\
3. & Pelayanan Pengisian Bahan Bakar Motor dengan Pembayaran Cash & 15,004 & 35 & Data Cukup \\
4. & Pelayanan Pengisian Bahan Bakar Motor dengan Pembayaran Cash & 10,43 & 35 & Data Cukup \\
5. & Pelayanan Pengisian Bahan Bakar Motor dengan Pembayaran Cash & 8,913 & 35 & Data Cukup \\
\hline
\end{tabular}

Tabel di atas menunjukkan hasil perhitungan N' tidak lebih dari $\mathrm{N}$ atau data yang telah diambil, maka dengan demikian jumlah data sudah mencukupi.

Tabel 11

Faktor penyesuaian pelayanan pengisian bahan bakar motor dengan pembayaran cash

\begin{tabular}{llcc}
\hline \multicolumn{1}{c}{ Faktor } & \multicolumn{1}{c}{ Indikator } & Kelas & Penilaian \\
\hline $\begin{array}{l}\text { Skill } \\
\text { (Keterampilan) }\end{array}$ & Gerakan-gerakan kerja beserta urutan-urutannya & Excellent & $+0,08$ \\
Effort & dijalankan tanpa kesalahan & (B2) & \\
& Penuh Perhatian pada pekerjaan, kecepatan baik & Good & $+0,02$ \\
Condition & Kondisi Lingkungan kerja cukup baik & (C2) & \\
& & Good & $+0,02$ \\
Consistency & Variabilitas waktu cukup rendah & (C) & $+0,01$ \\
& & Good & $(\mathrm{C})$ \\
\hline \multicolumn{2}{c}{ Jumlah } & & $+0,13$ \\
& Faktor Penyesuaian & & 1,13 \\
\hline
\end{tabular}

Tabel 12

Waktu normal

\begin{tabular}{|c|c|c|}
\hline & Waktu Siklus Rata-rata & Faktor Penyesuaian \\
\hline & 0,417 & 1,13 \\
\hline Waktu Normal & \multicolumn{2}{|c|}{$0,417 \times 1,13=0,471$ Menit } \\
\hline
\end{tabular}


Tabel 13

Faktor kelonggaran untuk menghilangkan rasa letih

\begin{tabular}{llc}
\hline \multicolumn{1}{c}{ Faktor } & \multicolumn{1}{c}{ Penilaian } & Penilaian Kelonggaran \\
\hline Tenaga yang dikeluarkan & Ringan & $6 \%$ \\
Sikap Kerja & Berdiri di atas dua kaki & $1,5 \%$ \\
Gerakan Kerja & Normal & 0 \\
Kelelahan Mata & Pandangan terputus-putus, pencahayaan baik & $5 \%$ \\
Keadaan Temperatur & Normal & $4 \%$ \\
Keadaan Atmosfer & Cukup baik & $1 \%$ \\
Keadaan Lingkungan & Cukup bising & $3 \%$ \\
\hline Total & & 20,5 \\
\hline
\end{tabular}

Tabel 14

Faktor kelonggaran

\begin{tabular}{lc}
\hline \multicolumn{1}{c}{ Kebutuhan Kelonggaran } & Penilaian Kelonggaran \\
\hline Kelonggaran untuk Kebutuhan Pribadi & $3 \%$ \\
Kelonggaran untuk Menghilangkan Rasa Letih & $20,5 \%$ \\
Kelonggaran untuk Hambatan Tak Terduga & $1 \%$ \\
Jumlah & $25,5 \%$ \\
\hline
\end{tabular}

Tabel 15

Waktu standar

\begin{tabular}{|c|c|c|}
\hline & Waktu Normal & Faktor Kelonggaran \\
\hline & 0,471 & $25,5 \%$ \\
\hline Waktu Standar & \multicolumn{2}{|c|}{0.63 Menit } \\
\hline
\end{tabular}

Perhitungan yang sama juga dilakukan pada pelayanan pengisian bahan bakar yang lainnya. Berikut ini rekapitulasi hasil perhitungan waktu standar semua pelayanan pengisian bahan bakar di SPBU XYZ.

Tabel 16

Rekapitulasi waktu standar

\begin{tabular}{|c|c|c|}
\hline No. & Elemen Pekerjaan & Waktu Standar (Menit) \\
\hline 1. & $\begin{array}{l}\text { Pelayanan Pengisian Bahan Bakar Motor } \\
\text { dengan Pembayaran Cash }\end{array}$ & 0,63 \\
\hline 2. & $\begin{array}{l}\text { Pelayanan Pengisian Bahan Bakar Mobil } \\
\text { dengan Pembayaran Cash }\end{array}$ & 1,3 \\
\hline 3. & $\begin{array}{l}\text { Pelayanan Pengisian Bahan Bakar Mobil } \\
\text { dengan Pembayaran Debit }\end{array}$ & 1,09 \\
\hline 4. & $\begin{array}{l}\text { Pelayanan Pengisian Bahan Bakar Truk } \\
\text { dengan Pembayaran Cash }\end{array}$ & 4,72 \\
\hline 5. & $\begin{array}{l}\text { Pelayanan Pengisian Bahan Bakar Truk } \\
\text { dengan Pembayaran Debit }\end{array}$ & 4,55 \\
\hline & Total Waktu Standar & 12,29 \\
\hline
\end{tabular}

\section{Perhitungan Penurunan Beban Kerja Mental}

Berdasarkan data seluruh waktu siklus pelayanan operator SPBU XYZ didapatkan total rata-rata waktu siklusnya adalah 8,24 menit, dengan total rata-rata waktu siklus tersebut, operator SPBU mendapatkan total rata-rata beban kerja mental sebesar 77,35, dimana nilai tersebut menunjukkan bahwa beban kerja mental yang didapatkan operator SPBU dikategorikan overload atau berlebihan. Beban kerja mental operator diketahui bahwa 3 indikator beban kerja tertinggi adalah effort, temporan demand, dan physical demand dimana 3 indikator tersebut memiliki kaitan erat dengan waktu.

Total waktu standar pelayanan operator SPBU XYZ dari hasil perhitungan adalah 12,29 menit. Jadi, apabila dengan waktu siklus kerja 8,24 menit menyebabkan tingginya beban kerja mental pada operator, maka setelah diketahuinya waktu standar dari setiap elemen pekerjaan operator SPBU XYZ akan dilakukan perhitungan untuk membuktikan bahwa skor beban kerja mental yang didapatkan operator dapat diturunkan dengan waktu standar yang telah ditentukan, karena pada penentuan waktu standar telah ditambahkan faktor 
penyesuaian dan faktor kelonggaran sebagai upaya untuk mengurangi beban kerja dana kelelahan kerja operator.

Berikut adalah perhitungan persentase penurunan beban kerja mental operator SPBU XYZ:

- Persentase Penambahan Waktu Siklus Kerja Operator

Dalam perhitungan penambahan persentase waktu siklus, menggunakan perhitungan matematika yaitu perhitungan persentase kenaikan.

$$
\begin{aligned}
& \text { Persentase }(\%)=\frac{\text { Total Waktu Standar }- \text { Total Rata-Rata Waktu Siklus }}{\text { Total Rata-Rata Waktu Siklus }} \times 100 \\
& \text { Persentase }(\%)=\frac{12,29-8,24}{8,24} \times 100=50 \%
\end{aligned}
$$

Persentase penambahan waktu kerja operator adalah 50\%. Persentase penambahan waktu kerja tersebut sama dengan persentase penurunan 3 indikator beban kerja mental yang memiliki skor rata-rata tertinggi yaitu effort, temporal demand, dan physical demand.

\section{- Penurunan Beban Kerja}

Berdasarkan hasil perhitungan persentase penambahan waktu kerja, diketahui bahwa penambahan waktu yaitu $50 \%$ maka dilakukan perhitungan pengurangan $50 \%$ skor 3 indikator tertinggi beban kerja mental, yaitu effort, temporal demand, dan physical demand.

Tabel 17

\begin{tabular}{|c|c|c|c|}
\hline Indikator & Physical Demand & Temporan Demand & Effort \\
\hline Operator 1 & 80 & 80 & 70 \\
\hline Operator 2 & 90 & 90 & 80 \\
\hline Operator 3 & 70 & 80 & 70 \\
\hline Operator 4 & 80 & 80 & 80 \\
\hline Operator 5 & 75 & 60 & 85 \\
\hline Operator 6 & 70 & 70 & 75 \\
\hline Operator 7 & 95 & 75 & 80 \\
\hline Operator 8 & 90 & 80 & 80 \\
\hline Operator 9 & 95 & 80 & 80 \\
\hline Operator 10 & 100 & 80 & 100 \\
\hline Operator 11 & 80 & 90 & 80 \\
\hline Operator 12 & 70 & 80 & 90 \\
\hline Operator 13 & 60 & 80 & 70 \\
\hline Operator 14 & 90 & 90 & 80 \\
\hline Operator 15 & 80 & 75 & 80 \\
\hline Operator 16 & 90 & 95 & 85 \\
\hline
\end{tabular}

Data rating NASA-TLX

Tabel 18

Penurunan 50\% data rating NASA-TLX

\begin{tabular}{cccc}
\hline Indikator & Physical Demand & Temporal Demand & Effort \\
\hline Operator 1 & 40 & 40 & 35 \\
Operator 2 & 45 & 45 & 40 \\
Operator 3 & 35 & 40 & 35 \\
Operator 4 & 40 & 40 & 40 \\
Operator 5 & 37,5 & 30 & 42,5 \\
Operator 6 & 35 & 35 & 37,5 \\
Operator 7 & 47,5 & 37,5 & 40 \\
Operator 8 & 45 & 40 & 40 \\
Operator 9 & 47,5 & 40 & 40 \\
Operator 10 & 50 & 40 & 50 \\
Operator 11 & 40 & 45 & 40 \\
Operator 12 & 35 & 40 & 45 \\
Operator 13 & 30 & 40 & 35 \\
Operator 14 & 45 & 45 & 40 \\
Operator 15 & 40 & 37,5 & 40 \\
Operator 16 & 45 & 47,5 & 42,5 \\
\hline
\end{tabular}


Perhitungan beban kerja mental dilakukan dengan menggunakan data hasil penurunan rating 3 indikator tertinggi beban kerja mental, dan didapatkan hasil perhitungan penurunan pembobotan beban kerja mental ditunjukkan pada Tabel 19.

Tabel 19

Rekapitulasi penurunan rata-rata beban kerja

\begin{tabular}{lcc}
\hline \multicolumn{1}{c}{ Indikator } & Total WWL & Rata-rata \\
\hline Mental Demand & 177,28 & 11,08 \\
Physical Demand & 125,83 & 7,86 \\
Temporal Demand & 127,85 & 7,99 \\
Performance & 178,27 & 11,14 \\
Frustation Level & 84,48 & 5,28 \\
Effort & 142,84 & 8,9275 \\
\hline Total Beban Kerja Mental & \multicolumn{2}{|}{} \\
\hline
\end{tabular}

Skor total penurunan beban kerja mental operator SPBU XYZ 32,30, dimana skor tersebut menunjukkan beban kerja mental operator optimal load. Jadi pada skor total waktu standar 12,29 menit mampu menurunkan beban kerja mental hingga 52,30. Jadi pada skor total waktu standar 12,29 menit mampu menurunkan beban kerja mental hingga 52,30. Klasifikasi penurunan beban kerja mental operator SPBU XYZ dapat dilihat pada tabel di bawah ini:

Tabel 20

Hasil perhitungan beban kerja mental operator SPBU

\begin{tabular}{cccc}
\hline No. & Operator & Rata-rata WWL & Klasifikasi Beban Kerja Mental \\
\hline 1 & Operator 1 & 51,67 & Tinggi \\
2 & Operator 2 & 49,33 & Cukup Tinggi \\
3 & Operator 3 & 44 & Cukup Tinggi \\
4 & Operator 4 & 50 & Tinggi \\
5 & Operator 5 & 47,17 & Cukup Tinggi \\
6 & Operator 6 & 47,67 & Cukup Tinggi \\
7 & Operator 7 & 51,17 & Tinggi \\
8 & Operator 8 & 50 & Tinggi \\
9 & Operator 9 & 59,33 & Tinggi \\
10 & Operator 10 & 70,67 & Tinggi \\
11 & Operator 11 & 50,33 & Tinggi \\
12 & Operator 12 & 55,33 & Tinggi \\
13 & Operator 13 & 42,33 & Cukup Tinggi \\
14 & Operator 14 & 52,67 & Tinggi \\
15 & Operator 15 & 54 & Tinggi \\
16 & Operator 16 & 61,17 & Tinggi \\
\hline
\end{tabular}

\section{- Persentase Penurunan Beban Kerja Operator}

Dalam perhitungan persentase penurunan beban kerja mental operator menggunakan perhitungan matematika yaitu perhitungan persentase penurunan.

$$
\begin{aligned}
& \text { Persentase }(\%)=\frac{\text { Total Rata-Rata Beban Kerja Awal-Total Rata-Rata Beban Kerja Akhir }}{\text { Total Rata-Rata Beban Kerja Awal }} \times 100 \\
& \text { Persentase }(\%)=\frac{77,35-52,30}{77,35} \times 100=32 \%
\end{aligned}
$$

Jadi persentase penurunan beban kerja mental operator SPBU XYZ yaitu sebesar 32\%. Dimana 32\% ini adalah persentase kenaikan utilitas stasiun pengisian bahan bakar SPBU XYZ. Sebelumnya terjadi penurunan utilitas yang ditunjukkan pada bagian 1 Pendahuluan Tabel 1 yaitu:

1. Stasiun 1, Minggu ke-3 dengan utilitas $71 \%$

2. Stasiun 2, Minggu ke-4 dengan utilitas $71 \%$

3. Stasiun 4, Minggu ke-1 dengan utilitas $71 \%$ dan Minggu ke-3 dengan utilitas 57\% 
Tabel di bawah ini hasil adalah meningkatnya utilitas, arena menurunnya persentase beban kerja mental yang didapatkan operator:

Tabel 21

Data peningkatan utilitas (\%) stasiun pengisian bahan bakar SPBU XYZ

\begin{tabular}{lcccc}
\hline Minggu & Stasiun 1 & Stasiun 2 & Stasiun 3 & Stasiun 4 \\
\hline Minggu ke 1 & 100 & 100 & 100 & 94 \\
Minggu ke 2 & 100 & 86 & 86 & 100 \\
Minggu ke 3 & 94 & 100 & 86 & 70 \\
Minggu ke 4 & 100 & 94 & 100 & 86 \\
\hline
\end{tabular}

Hasil perhitungan peningkatan utilitas stasiun pengisian bahan bakar, masih terdapat stasiun pengisian yang tidak mencapai target utilitas, yaitu pada Stasiun 4 minggu ke-3 dengan nilai utilitas 70\%. $70 \%$ didapatkan dari hasil perhitungan kenaikan utilitas stasiun pengisian.

\section{KESIMPULAN}

\section{A. Kesimpulan}

Berdasarkan hasil pengolahan dan analisis data, kesimpulan dari penelitian ini adalah:

1. Hasil perhitungan total skor beban kerja mental operator SPBU XYZ adalah 77,35, skor tersebut menunjukkan bahwa beban kerja mental yang didapatkan oleh operator SPBU XYZ overload. Dengan klasifikasi beban kerja mental dari setiap operatornya juga tinggi dan sangat tinggi. Dan rata-rata skor penilaian untuk kelelahan kerja yaitu 37,75, yang berarti tingkat kelelahan kerja yang dialami oleh operator SPBU masuk ke dalam kategori kelelahan sedang yang dimana pihak perusahaan mungkin diperlukan adanya tindakan perbaikan dalam menyikapi dan mengatasi penyebab kelelahan kerja yang nantinya akan menimbulkan gangguan kesehatan pada operator.

2. Waktu standar dari setiap elemen kerja yang didapatkan antara lain :

a. Pelayanan pengisian bahan bakar motor dengan pembayaran cash adalah 0,63 menit

b. Pelayanan pengisian bahan bakar mobil dengan pembayaran cash adalah 1,3 menit

c. Pelayanan pengisian bahan bakar mobil dengan pembayaran debit adalah 1,09 menit

d. Pelayanan pengisian bahan bakar truk dengan pembayaran cash adalah 4,72 menit

e. Pelayanan pengisian bahan bakar truk dengan pembayaran debit adalah 4,55 menit

3. Penurunan skor beban kerja mental operator SPBU XYZ mencapai 52,30 yang menunjukkan beban kerja yang akan didapatkan operator SPBU optimal load dengan persentase penurunan $32 \%$ yang merupakan persentase kenaikan utilitas hingga mencapai target.

\section{B. Saran}

1. Untuk stasiun pengisian yang masih belum mencapai standar utilitas, pihak manajemen SPBU XYZ bisa menambah man power sebagai salah satu solusi.

2. Diharapkan pihak manajemen SPBU XYZ lebih memperhatikan lagi bagaimana tingkat beban kerja mental dan kelelahan kerja yang didapatkan operator SPBU.

\section{DAFTAR PUSTAKA}

Hämäläinen P., Takala J., Boon Kiat T., 2017. Perkiraan Global Kecelakaan Kerja dan Penyakit yang Berhubungan dengan Kerja, Kongres Dunia XXI tentang Keselamatan dan Kesehatan di Tempat Kerja. Singapura: Lembaga Keselamatan dan Kesehatan Kerja.

Pratiwi, I. P., Astuti, R. D., \& Jauhari, W. A. (2019). Analisis Beban Kerja dan Kelelahan Kerja pada Pegawai Bagian Penyelenggaraan E-Goverment. Seminar dan Konferensi Nasional IDEC, B06.1 - B06.8.

Montororing, Y.D.R. 2018. Usulan Penentuan Waktu Baku Proses Racking Produk Amplimesh Dengan Metode Jam Henti Pada Departemen Powder Coating. Jurnal Teknik FT UMT. Vol 7. No 2. 
Montororing, Y.D.R., \& Sihombing, S. 2020. Perancangan Alat Bantu Kerja Dengan Prinsip Ergonomi Pada Bagian Penimbangan di PT.BPI. Jurnal Inkofar. Vol 1. No.2.

Sutalaksana I.Z. 2006. Teknik Perancangan Sistem Kerja. Institut Teknologi Bandung, Bandung

Tarwaka. (2015). ERGONOMI INDUSTRI Dasar-Dasar Pengetahuan Ergonomi dan Aplikasi Di Tempat Kerja. Surakarta: Harapan Press.

Widyanti, A., Johnson, A., \& Waard, D. (2010). Pengukuran Beban Kerja Mental Dalam Searching Task Design Metode Rating Mental Effort (RSME). J@TI UNDIP, 1 - 6.

Yanto, \& Ngaliman, B. (2017). ERGONOMI Dasar-Dasar Studi Waktu dan Gerakan untuk Analisis dan Perbaikan Sistem Kerja. Jakarta: Penerbit ANDI Yogyakarta.

Hart, S., \& Staveland, L. (1988). Development of NASA Task Load Index (TLX): Results of Empirical and Theoritical Research. NASA-Ames Research, California.

Iridiastadi, H \& Yasierly. (2014). Ergonomi Suatu Pengantar, Edisi kedua. Bandung: Remaja Rosdakarya.

Wignjosoebroto. (2008). Ergonomic Studi Gerak dan Waktu: Teknik Analisis Untuk Peningkatan Produktivitas Kerja. Surabaya: Guna Widya.

Ramli S. 2010. Sistem Manajemen Keselamatan \& Kesehatan Kerja. OHSAS 18001. Jakarta: Dian Rakyat 